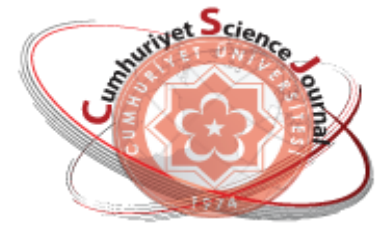

e-ISSN: $2587-246 X$

ISSN: $2587-2680$

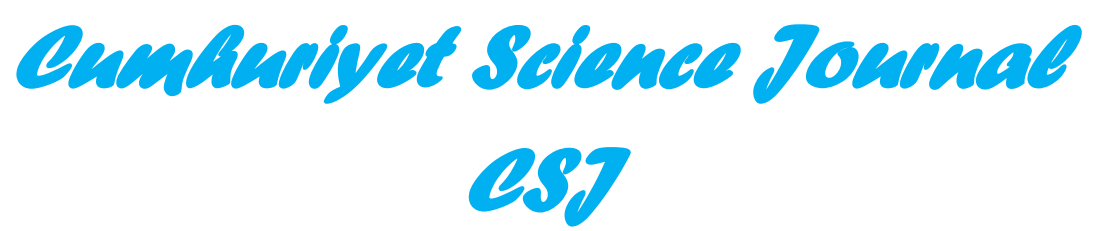

Cumhuriyet Sci. J., Vol.39-2(2018) 349-356

\title{
Levels and effects of natural radionuclides in sediment banks of Rhumel River (Northeast Algeria)
}

\author{
Ghania BOUHILA ${ }^{1 *}$, Fatima BENRACHI ${ }^{1}$, Mourad RAMDHANE ${ }^{2}$ \\ ${ }^{I}$ Frères Mentouri Constantine University, Laboratory of Mathematical and Subatomic Physics (LPMS), ALGERIA \\ ${ }^{2}$ LPSC, Université Grenoble Alpes, CNRS/IN2P3, Institut Nationale Polytechnique de Grenoble, Grenoble Cedex \\ FRANCE \\ Received: 01.12.2017; Accepted: 22.03.2018 \\ http://dx.doi.org/10.17776/csj.360133
}

\begin{abstract}
Activity concentrations of natural radionuclides in Boumerzoug River sediment (the main tributary of Rhumel river) have been measured using high resolution HPGe detector. The activity concentrations of the samples were range from $16.66 \pm 2.32 \mathrm{~Bq} / \mathrm{kg}$ to $43.48 \pm 4.03 \mathrm{~Bq} / \mathrm{kg}$ with mean value of $26.64 \pm 1.33 \mathrm{~Bq} / \mathrm{kg}$ for ${ }^{226} \mathrm{Ra}, 20.01 \pm 1.98 \mathrm{~Bq} / \mathrm{kg}$ to $32.71 \pm 3.85 \mathrm{~Bq} / \mathrm{kg}$ with the mean value $25.95 \pm 1.46 \mathrm{~Bq} / \mathrm{kg}$ for ${ }^{232} \mathrm{Th}$ and $81.70 \pm 33.59 \mathrm{~Bq} / \mathrm{kg}$ to $259.20 \pm 38.80 \mathrm{~Bq} / \mathrm{kg}$ with the mean value $164.50 \pm 11.30 \mathrm{~Bq} / \mathrm{kg}$ for ${ }^{40} \mathrm{~K}$. These values were used to estimate the radiation hazard indices. The absorbed dose and annual effective dose were evaluated to assess the radiation risk due to the use of these sediments.
\end{abstract}

Keywords: River sediment, Natural Radioactivity, HPGe Detector, Radiation Hazards

\section{Rhumel Nehrinin (Kuzeydoğu Cezayir) çökelti kümelerinde doğal radyonüklidlerin seviyeleri ve etkileri}

\begin{abstract}
Özet: Boumerzoug nehri tortusunda (Rhumel nehrinin ana kolu) doğal radyonüklidlerin aktivite konsantrasyonları, yüksek çözünürlüklü HPGe detektörü kullanılarak ölçülmüştür. Örneklerin aktivite

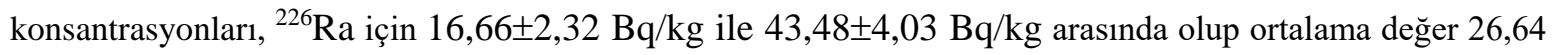

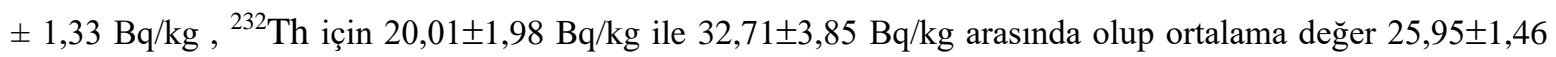
$\mathrm{Bq} / \mathrm{kg}$, son olarak ${ }^{40} \mathrm{~K}$ için $81,70 \pm 33,59 \mathrm{~Bq} / \mathrm{kg}$ ile $259,20 \pm 38,80 \mathrm{~Bq} / \mathrm{kg}$ arasında olup ortalama değeri $164,50 \pm 11,30 \mathrm{~Bq} / \mathrm{kg}$ 'dir. Bu değerler radyasyon tehlikesi endekslerini tahmin etmek için kullanılmıştır. Bu tortuların kullanımına bağlı radyasyon riskini değerlendirmek için emilen doz ve yıllık etkili doz değerlendirilmiştir.
\end{abstract}

Anahtar Kelimeler: Nehir çökeltisi, Doğal Radyoaktivite, HPGe Dedektörü, Radyasyon Tehlikesi

\section{INTRODUCTION}

Among the different geological formations in environment, sediment plays an important role in aquatic radioecology, since it acts as a medium of migration for the transfer of radionuclides to the biological systems [1-2]. Also, sediment is the most important source of continuous radiation exposure for human. For this reason, sediment is regarded the basic indicator of radiological contamination in the environment [1-3].

\footnotetext{
* Corresponding author. Email address: bouhilaghania@yahoo.fr http://dergipark.gov.tr/csj C2016 Faculty of Science, Cumhuriyet University
} 
Most of the sediments that settle in river were formed when the rock and organic materials are broken into small pieces by moving in the water [3]. Therefore, the natural radionuclides concentration in the rock would affect radioactivity level of the river sediment because the breaking of a rock into pieces does not change its chemical composition [1-4]. In addition, some human activities can enhance the levels of radioactivity in river sediments, because it may be regarded as environmental host for many of the waste products discharged by society [5]. The presence of natural radionuclides in sediment by high levels may be lead to radiological risks to the human health, since these radioactive elements in sediment dissolve in water over time and may be transferred to water resources, plants and animals, then to human.

The knowledge of radionuclides distributions in the sediments acts an essential part in monitoring of environmental contamination and assessment of radiological hazard arising from natural sources. For this purpose, in the recent years many studies give an importance to the measurements of the activity concentrations of natural radionuclides and their hazard on human health [1-14].

In several areas of Algeria, especially in the big cities, rivers have been polluted by industrial and agricultural human activities, or waste disposal. Among the watercourse in northeast of Algeria; Rhumel River is a very important aquatic ecosystem in the region. This stream has a vital role, since it feeds Beni Haroun dam; the largest dam in Algeria. In addition, the waters of the river are exploited to irrigate the agricultural lands neighboring of stream.

This river represents the main rivers in the east of Algeria. Originates at around 1160 in the southern margins of Tell, North-West of Balaâ (125 km from El-Eulma, Setif), Rhumel River flows through high plain of Constantine. It drains an orientation South-West -North-East, after that it crosses the rock Constinoise deeply sinking $(200 \mathrm{~m}$ in level $)$ into gorge of limestone. Then, it suddenly changes the direction and turns to the right and flows obliquely towards the northwest, it confluences with Oued Endja around Sidi Merouene in Mila town. Its length is of $200 \mathrm{~km}$ and covers an area of $5315 \mathrm{~km}^{2}$ [15]. The river basin climate is a semiarid type; characterized by wet winters and dry and hot summers [15-16].

The main tributary of the river is Oued Boumerzoug which drains industrial and urban zones. Along of its path, the river basin includes several agricultural lands where the farmers use often the fertilizers. Although the importance of this watercourse in northeast of Algeria, no studies are found concerning the level of natural radioactivity about this aquatic ecosystem. This work aims to evaluate the radioactivity concentrations in some sediment samples collected of Rhumel River as well as assessment of radiological parameters.

\section{MATERIALS and METHODS}

\subsection{Sample collection and Measurement}

In order to evaluate the natural radioactivity levels, the sediment samples were collected from several locations along the Boumerzoug River (tributary of Rhumel River) at a depth of $5-10 \mathrm{~cm}$ from the top surface layer. In the first and second locations (SRBD), (SRBB) in El Djedour city, the river passes through several farming fields in these areas. The third region (SRBH) is located near Industrial Zone (oued Hamimime). The fourth site (SRBQ) is located near Boumerzoug city and the fifth (SRBM) is located under the El Mouzina Bridge in El khroub city (Fig.1).

The samples were dried, pulverized, homogenized, weighed and packed into small cylindrical plastic containers approximately for 30 days $(\sim 7$ half-lives) to reach secular equilibrium between the ${ }^{238} \mathrm{U}$ and ${ }^{232} \mathrm{Th}$ series and their respective progeny before measurements $[11,17]$. The natural radioactivity of samples was measured at low activity laboratory (LBA/LPSC-Grenoble) which has two HPGe detectors. Both detectors are 
surrounded by $2 \mathrm{~cm}$ of archeological lead and by $15 \mathrm{~cm}$ of purified lead. The two detectors and the lead plate are placed at the center of a two meter high cube; each face of this cube being constituted with a liquid scintillation detector. These detectors proceed as dynamic veto stopping the acquisition of data during the passage of a cosmic ray.

The data acquisition and analysis use two PCs equipped with the "Interwinner" (ITECHinstruments) software. The detectors have a relative efficiency of $20 \%$ and the energy resolution was of 0.78 and $1.85 \mathrm{keV}$ at $122 \mathrm{keV}$ $\left({ }^{57} \mathrm{Co}\right)$ and $1332 \mathrm{keV}\left({ }^{60} \mathrm{Co}\right)$ gamma lines, respectively [18]. IAEA-RGU-1 and IAEARGTh-1, in powder form, installed in the same position and plastic bottle as the samples, were used to determine the detectors efficiency curves. The activities of the natural-series were $4940 \pm 30 \mathrm{~Bq} / \mathrm{kg}$ for ${ }^{238} \mathrm{U}$ and $228 \pm 2 \mathrm{~Bq} / \mathrm{kg}$ for ${ }^{235} \mathrm{U}$ in IAEA-RGU-1 and $3250 \pm 10 \mathrm{~Bq} / \mathrm{kg}$ for ${ }^{232} \mathrm{Th}$ in IAEA-RGTh-1 [19].

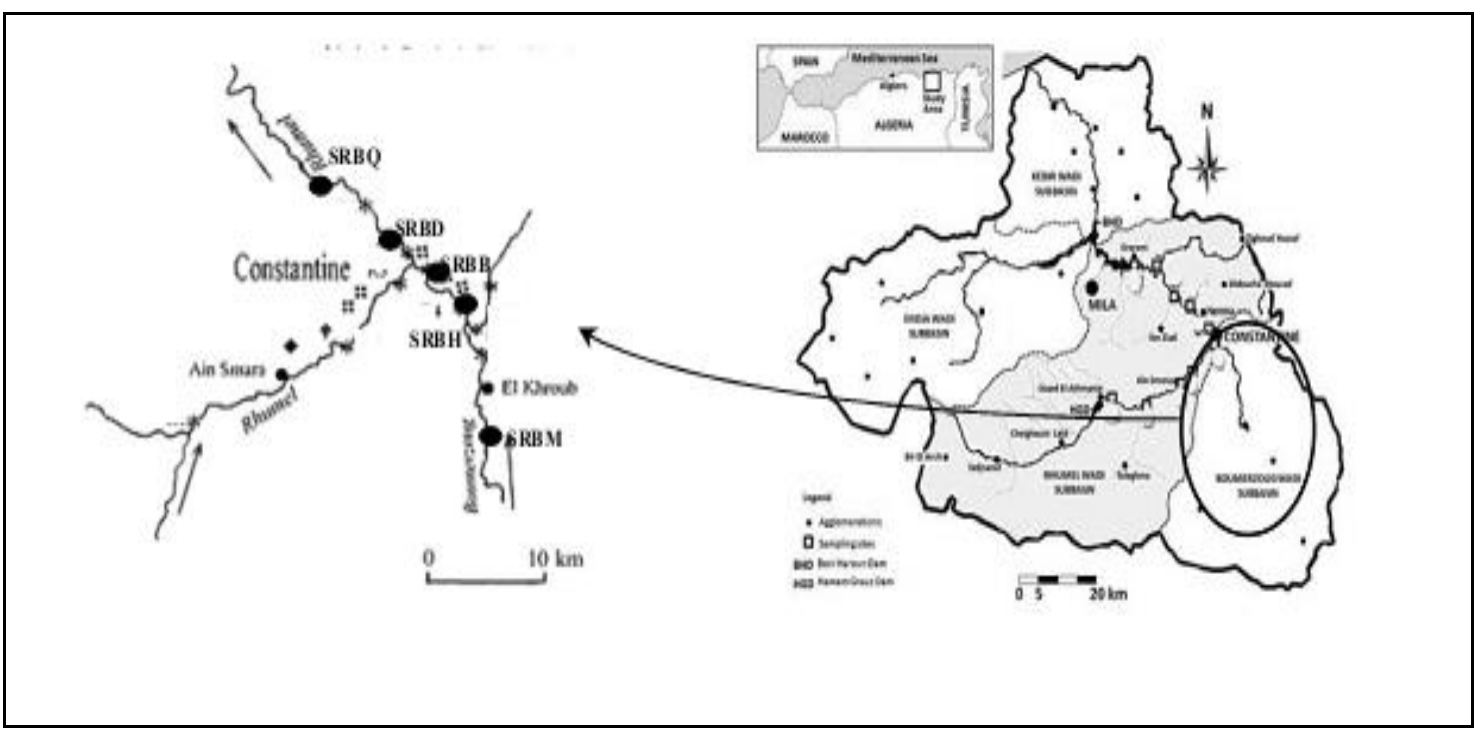

Figure 1. Sampling locations in Rhumel basin.

Each sample was measured for 48 hours. The measured prominent gamma-ray lines from both the Uranium and Thorium decay series were used for sample analysis to determine the activity concentration after correcting by background counts. The activity concentrations were determined for ${ }^{232} \mathrm{Th}$ assuming secular equilibrium with their decay products. The gamma-ray transitions of ${ }^{228} \mathrm{Ac}(338.4,911.2$ $\mathrm{keV}),{ }^{212} \mathrm{~Pb}(238.6 \mathrm{keV})$ and ${ }^{208} \mathrm{Tl}(583.1 \mathrm{keV})$ were used. The activity concentrations of ${ }^{226} \mathrm{Ra}$ were measured from gamma-ray transition of ${ }^{214} \mathrm{~Pb}(351.9 \mathrm{keV})$ and ${ }^{214} \mathrm{Bi}(609.3 \mathrm{keV}) .{ }^{40} \mathrm{~K}$ was determined from the $1460.8 \mathrm{keV}$ peak. The activity concentrations for the natural radionuclides in the measured samples were evaluated using the relation:

$A_{s}=\frac{N_{E}}{\varepsilon_{E} p t m}$

Where: $N_{E}$ and $\varepsilon_{E}$ are the net peak area and the detection efficiency at energy $\mathrm{E}, p$ is the branching ratio of radionuclide of interest; $t$ is the counting time $(\mathrm{s}) ; m$ is the mass of the measured sample in $\mathrm{kg}$. 


\subsection{Radiation hazard indexes and Dose Estimation}

In order to compare the activity concentration and radiological affects of sediment samples, which contain ${ }^{226} \mathrm{Ra},{ }^{232} \mathrm{Th}$ and ${ }^{40} \mathrm{~K}$, the radium equivalent activity $\left(\mathrm{Ra}_{\mathrm{eq}}\right)$ as common index has been introduced [20]:

$$
R a_{e q}=0.077 A_{k}+1.43 A_{T h}+A_{R a}
$$

Where $A_{k}, A_{T h}$ et $A_{R a}$ are the concentrations of ${ }^{40} \mathrm{~K},{ }^{232} \mathrm{Th}$ and ${ }^{226} \mathrm{Ra}$ respectively.

Many other significant factors are dependent on the evaluation of the activity concentrations of ${ }^{226} \mathrm{Ra}$. The first factor is named Internal Hazard Index $\mathrm{H}_{\text {in }}$ which represents radiation hazard to respiratory organs due to ${ }^{222} \mathrm{Rn}$ and ${ }^{220} \mathrm{Rn}$ and their progenies. This index is defined as follows [20]:

$H_{\text {in }}=\frac{A_{R a}}{185}+\frac{A_{T h}}{259}+\frac{A_{K}}{4810}$

The second factor is named External Hazard Index $\mathrm{H}_{\mathrm{ex}}$ reflecting the external exposure, which is given by [20]:

$H_{e x}=\frac{A_{R a}}{370}+\frac{A_{T h}}{259}+\frac{A_{K}}{4810}$

The values of the indices $\left(H_{i n}, H_{e x}\right)$ must be less than unity for the radiation hazard to be negligible.

Another radiation hazard index called the representative level index $I_{\gamma}$ is defined by [21]:

$I_{\gamma}=\frac{A_{R a}}{150}+\frac{A_{T h}}{100}+\frac{A_{K}}{1500}$

To assess the absorbed dose rates in outdoor (D) due to gamma radiations in air at $1 \mathrm{~m}$ above the ground surface for the uniform distribution of the naturally occurring radionuclides $\left({ }^{226} \mathrm{Ra}\right.$, ${ }^{232} \mathrm{Th}$ and ${ }^{40} \mathrm{~K}$ ) in the studied samples the following equation is used [22]:

$$
D\left(n G y h^{-1}\right)=0.462 A_{R a}+0.621 A_{T h}+0.041 A_{K}
$$

The conversion factors used to compute absorbed $\gamma$ dose rate (D) in air per unit activity concentration in $\mathrm{Bq} / \mathrm{kg}$ (dry-weight) correspond to $0.462 n G y h^{-1}$ for ${ }^{226} \mathrm{Ra}$ (of U- series), 0.621 $n G y h^{-1}$ for ${ }^{232} \mathrm{Th}$ and $0.0417 n G y h^{-1}$ for ${ }^{40} \mathrm{~K}$. To estimate the annual effective dose rates (AED), the conversion coefficient from absorbed dose in air to effective dose (0.7) and outdoor occupancy factor (0.2) proposed by UNSCEAR [22] were used. Therefore, the annual effective dose rate $\left(\mu \mathrm{Sv} \mathrm{yr}^{-1}\right)$ was calculated by the formula:

$A E D\left(\mu S v y^{-1}\right)=D\left(n G y \cdot h^{-1}\right) \times 8760 h \times 0.7 S v G y^{-1} \times 10^{-3} \times 0.2$

\section{RESULTS and DISCUSSION}

Radionuclides activity concentrations measured in the sediment samples are presented in (Fig.2) which shows that the concentrations varied from site to site because the river sediment can exhibit large variation in composition [4]. Also, it can be seen that the ${ }^{40} \mathrm{~K}$ activity is the largest contributor to the total activity for all the samples with the mean value of $164.50 \pm 11.3$ $\mathrm{Bq} / \mathrm{kg}$, this due to the presence of clays in these locations. In general, the clays and shales contain relatively high concentration of radioactive isotopes, notably potassium [23]. The mean activity concentrations of ${ }^{226} \mathrm{Ra}$ and ${ }^{232} \mathrm{Th}$ in the river samples are $26.64 \pm 1.33$ and $25.95 \pm 1.46 \mathrm{~Bq} / \mathrm{kg}$ respectively, as shown in (Table. 1). However, no artificial radionuclide was detected at any studied site.

The radiological hazard parameters are calculated from the measured activity concentrations of three main radionuclides in all sediment samples and are listed in (Table.1). It can be seen that the values $\mathrm{Ra}_{\mathrm{eq}}$ of all sediment samples in the present work are lower than the accepted safety limit value of $370 \mathrm{~Bq} / \mathrm{kg}$ [22]. The results obtained for internal and external hazard indexes $\left(H_{i n}, H_{e x}\right)$ are below than the limit of unity and the $\mathrm{I}_{\gamma}$ values of the measured samples are within the limit. Also, the estimated absorbed dose and the annual effective dose 
rates for the investigated samples ranged from $24,28 \pm 1.95$ to $50,46 \pm 3.69 \mathrm{nGyh}^{-1}$ and $29.79 \pm 2.40$ to $61.93 \pm 4.54 \mu \mathrm{Svyr}^{-1}$ respectively, with the mean values of $35,00 \pm 3.69 \mathrm{nGyh}^{-1}$ and $40.64 \pm 4.54 \mu \mathrm{Svyr}^{-1}$. The obtained values are less than the world average values of $59 \mathrm{nGyh}^{-1}$ and $70 \mu$ Svyr $^{-1}$ given by UNSCEAR [22].

(Fig.3) shows the linear correlation between ${ }^{226} \mathrm{Ra}$ and ${ }^{232} \mathrm{Th}$ activity concentrations, to know the extent of the existence of these radionuclides together in study area. Positive correlation was observed between the activities of radionuclides. These results indicate that the samples collected from this region are geochemically coherent; which means that the individual result for any one of the radionuclide concentration in this pair is a good predictor of the concentration of the other and they belong to same source [24].

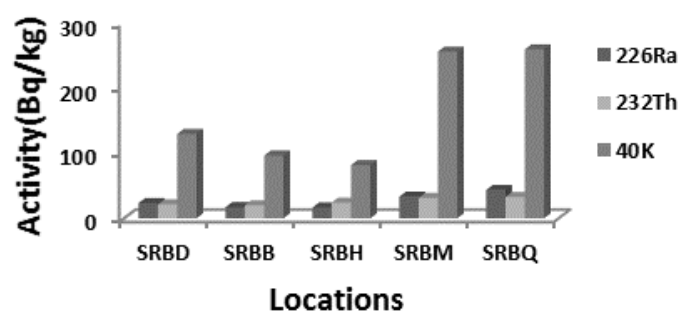

Figure 2. Comparison of activity concentrations of ${ }^{226} \mathrm{Ra}$, ${ }^{232} \mathrm{Th}$ and ${ }^{40} \mathrm{~K}$ in study location.

Table 1. The activity of ${ }^{226} \mathrm{Ra},{ }^{232} \mathrm{Th}$ and ${ }^{40} \mathrm{~K}$ in $(\mathrm{Bq} / \mathrm{kg})$ and Radiation hazard parameters.

\begin{tabular}{|c|c|c|c|c|c|c|c|c|c|}
\hline \multirow[b]{2}{*}{ Locations } & \multicolumn{3}{|c|}{ Concentration $(\mathrm{Bq} / \mathrm{Kg})$} & \multicolumn{4}{|c|}{ Radiation hazard indexes } & \multicolumn{2}{|c|}{ Dose estimation } \\
\hline & ${ }^{226} \mathbf{R a}$ & ${ }^{232} \mathrm{Th}$ & ${ }^{40} \mathrm{~K}$ & $\begin{array}{c}\text { Raeq } \\
(\mathrm{Bq} / \mathrm{kg})\end{array}$ & $\mathbf{H}_{\mathrm{ex}}$ & $\mathbf{H}_{\text {in }}$ & $\mathbf{I}_{\gamma}$ & $\begin{array}{c}\text { D } \\
\left(\mathrm{nGyh}^{-1}\right)\end{array}$ & $\begin{array}{c}\text { AED } \\
\left(\mu \mathrm{Svyr}^{-1}\right)\end{array}$ \\
\hline SRBB & $17.19 \pm 2.17$ & $20.01 \pm 1.98$ & $96.31 \pm 27.80$ & $53.35 \pm 4.16$ & $0.14 \pm 0.01$ & $0.19 \pm 0.02$ & $0.38 \pm 0.03$ & $24.28 \pm 1.95$ & $29.79 \pm 2.39$ \\
\hline SRBH & $16.66 \pm 2.32$ & $24.19 \pm 3.59$ & $81.70 \pm 33.59$ & $57.54 \pm 6.19$ & $0.16 \pm 0.02$ & $0.20 \pm 0.02$ & $0.41 \pm 0.05$ & $25.99 \pm 2.83$ & $31.89 \pm 3.47$ \\
\hline SRBQ & $43.48 \pm 4.03$ & $32.71 \pm 3.85$ & $259.20 \pm 38.80$ & $109.55 \pm 7.45$ & $0.30 \pm 0.02$ & $0.41 \pm 0.02$ & $0.79 \pm 0.05$ & $50.46 \pm 3.42$ & $61.93 \pm 4.19$ \\
\hline Mean & $26.64 \pm 1.33$ & $25.95 \pm 1.46$ & $164.50 \pm 11.30$ & $76.42 \pm 7.45$ & $0.21 \pm 0.03$ & $0.28 \pm 0.02$ & $0.55 \pm 0.05$ & $35.00 \pm 3.42$ & $40.64 \pm 4.19$ \\
\hline
\end{tabular}

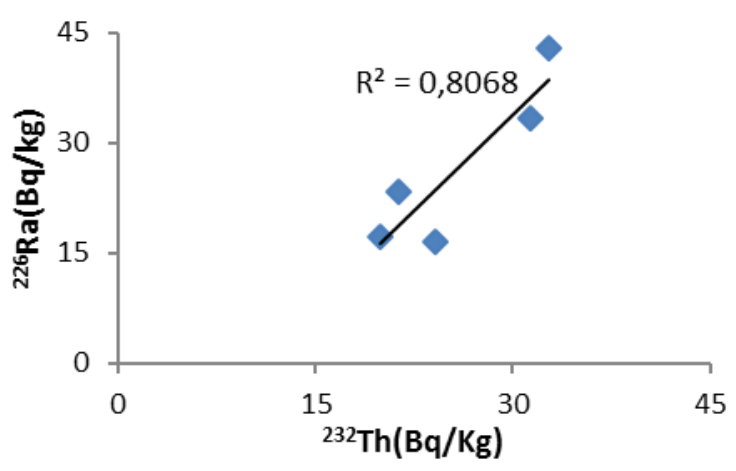

Figure 3. Correlation between ${ }^{226} \mathrm{Ra}$ and ${ }^{232} \mathrm{Th}$ in the study area.
The average values of ${ }^{226} \mathrm{Ra},{ }^{232} \mathrm{Th}$ and ${ }^{40} \mathrm{~K}$ activity concentrations in sediment samples from studies area were compared with similar investigations in other countries and summary of results is given in (Table 2).

The measured values of ${ }^{226} \mathrm{Ra},{ }^{232} \mathrm{Th}$ and ${ }^{40} \mathrm{~K}$ concentrations in the present work were within the world average according to UNSCEAR (2000) report. 
Table 2. Comparison of natural radionuclides concentrations in sediment samples under investigation with those in other countries.

\begin{tabular}{ccccc}
\hline Locations & ${ }^{226} \mathrm{Ra}$ & ${ }^{232} \mathrm{Th}$ & ${ }^{40} \mathrm{~K}$ & References \\
\hline Algeria & $26.64 \pm 1.33$ & $25.95 \pm 1.46$ & $164.50 \pm 11.30$ & Present work \\
Italy & $72.00 \pm 31.00$ & $48.00 \pm 8.90$ & $617.00 \pm 150.00$ & {$[25]$} \\
Thailand & $60.20 \pm 0.50$ & $64.97 \pm 0.50$ & $431.87 \pm 5.90$ & {$[26]$} \\
Turkey & $18.90 \pm 1.20$ & $27.20 \pm 1.70$ & $524.0 \pm 24.30$ & {$[13]$} \\
Egypt & $16.30 \pm 9.22$ & $12.49 \pm 6.23$ & $200.21 \pm 52.94$ & {$[7]$} \\
Sudan & $22.83 \pm 4.03$ & $25.11 \pm 4.96$ & $284.31 \pm 80.45$ & {$[27]$} \\
Ghana & $16.02 \pm 9.99$ & $20.31 \pm 16.39$ & $195.01 \pm 116.49$ & {$[28]$} \\
Nigeria & $180.59 \pm 15.04$ & $187.12 \pm 54.82$ & $329.00 \pm 19.00$ & {$[29]$} \\
World average & 35 & 30 & 400 & {$[22]$} \\
\hline
\end{tabular}

As shown in (Table 2), it can be seen that the mean value of ${ }^{40} \mathrm{~K}$ in investigation area is lower than the other countries. ${ }^{226} \mathrm{Ra}$ concentration is slightly higher than Ghana, Egypt and Turkey, but it is lower than the other countries. While ${ }^{232} \mathrm{Th}$ mean value is close to Ghana, Sudan and Egypt, however, it is less than Nigeria, Italy and Thailand.

\section{CONCLUSION}

The present study has been carried out to establish baseline data regarding concentration levels of naturally occurring radionuclides ${ }^{226} \mathrm{Ra},{ }^{232} \mathrm{Th}$ and ${ }^{40} \mathrm{~K}$ in Boumerzoug River sediments the main tributary of Rhumel River. The measurements showed that natural radionuclides of ${ }^{238} \mathrm{U}$ and ${ }^{232} \mathrm{Th}$ chains and ${ }^{40} \mathrm{~K}$ are present in all samples where the results obtained for activity concentrations are lower than the world wide average identified by UNSCEAR [22]. The values of the radiation hazard parameters of these sediment samples are not high compared to the world averages. Also, the estimated dose and the annual effective dose rates in the studied area are less than the recommended values. Hence, the results in this current study can be used as a baseline for the observation of any possible change in the future.

\section{REFERENCES}

[1] Lu X., Zhang X., Wang F., Natural radioactivity in sediment of Wei River,
China, Environ. Geol. 53 (2008) 14751481.

[2] Agbalagba E.O., R.A. Onoja, Evaluation of natural radioactivity in soil, sediment and water samples of Niger Delta (Biseni) flood plain lakes, J. Environ. Radioactiv. 102 (2011) 667-671.

[3] El-Reefy H.I., Sharshar T., Elnimr T., Badran H. M., Distribution of gamma-ray emitting radionuclides in the marine environment of the Burullus Lake: II. Bottom sediments, Environ. Monit. Assess. 169 (2010) 273-284.

[4] Krmar M., Slivka J., Varga E., Bikit I, Vesković M., Correlations of natural radionuclides in sediment from Danube, J. Geochem. Explor. 100 (2009) 20-24.

[5] Taher A. El and Abday A.G.E., Natural radioactivity levels and associated radiation hazards in Nile river sediments from Aswan to El-Minia, Upper Egypt, IJPAP. 50 (2012) 224-230.

[6] Sam A.K., Ahmed M.M.O., El Khangi F. A., El Nigumi Y. O., and Holm E., Assessment of terrestrial gamma radiation in Sudan, Radiat. Prot. Dosim. 71 (1997) 141-145.

[7] El-Gamal A., Nasr S., El-Taher A., Study of the spatial distribution of natural radioactivity in the upper Egypt Nile River sediments, Radiat. Meas. 42 (2007) 457-465.

[8] Jibiri N.N. and Okeyode I.C, Activity concentrations of natural radionuclides in the sediments of ogun river, southwestern 
Nigeria, Radiat. Prot. Dosim. 147, 555564 (2011).

[9] Agbalagba E.O., Avwiri G.O., ChadUmoreh Y.E., $\quad J . \quad \gamma$-Spectroscopy measurement of natural radioactivity and assessment of radiation hazard indices in soil samples from oil fields environment of Delta State, Nigeria, Environ. Radioactiv. 109 (2012) 64-70.

[10] Eroglu H., and Kabadayi Ö., Natural radioactivity levels in lake sediment samples Radiat. Prot. Dosim. 100 (2013) 1-5.

[11] Santawamaitre T., Malain D., Al-Sulaiti H.A., Bradley D. A., Matthews M.C., Regan P.H., Determination of ${ }^{238} \mathrm{U},{ }^{232} \mathrm{Th}$ and ${ }^{40} \mathrm{~K}$ activity concentrations in riverbank soil along the Chao Phraya river basin in Thailand J. Environ. Radioactiv. 138 (2014) 80-86.

[12] Moherye M., Baz S, Kelany A. M. , Abdallah A. M. , Environmental radiation levels in soil and sediment samples collected from floating water from a land runway resulting from heavy rains in the Jeddah region, KSA, Radiat Phys. Chem. 97 (2014) 16-24.

[13] Yildız N., Oto B., Turhan S., Uğur F.A., Gören E., Radionuclide determination and radioactivity evaluation of surface soil samples collected along the Erçek lake basin in eastern Anatolia, Turkey, $J$. Geochem. Explor. 146 (2014) 34-39.

[14] Bajoga A.D., Alazemi N., Regan P.H., Bradley D.A., Radioactive investigation of NORM samples from Southern Kuwait soil using high-resolution gamma-ray spectroscopy, Radiat. Phys. Chem. 116 (2015) 305-311.

[15] Mebarki A. Ressources en eau et aménagement en Algérie. Le bassin du Kébir-Rhumel. Alger University Publications Office (1984).

[16] Azzouz S., Chellat S., Boukhalfa C., Amrane A., Spatial Evolution of Phosphorus Fractionation in the Sediments of Rhumel River in the
Northeast Algeria, Environ. Pollut., 3 (2014) 51-59.

[17] Nada A., Abd-El Maksoud T. M., AbuZeid Hosnia M., El-Nagar T., Awad T. S. Distribution of radionuclides in soil samples from a petrified wood forest in El-Qattamia, Cairo, Egypt, Appl. Radiat. Isotopes. 67 (2009) 643-649.

[18] Laboratoire de Physique Subatomique \& Cosmologie, IN2P3 (CNRS), Universite Grenoble Alpes, Observation du boson de Higgs en association avec une paire de quarks top (ttH). Available at: http://lpsc.in2p3.fr. Retrieved June 14, 2018. (Sample reference of website)

[19] Preparation of gamma-ray spectrometry reference materials RGU-1, RGTh- 1 and RGK-1 report -AIEA /RL/148, Vienna, 1987.

[20] Beretka J., Mathew P. J., Natural radioactivity of Australian building materials industrial wastes and byproducts, Health Phys. 48 (1985) 87-95.

[21] NEA-OECD, Exposure to radiation from natural Radioactivity in building materials; Report by NEA of experts of the Nuclear Energy Agency. OECD, Paris, France (1979).

[22] United Nations Scientific Committee on the Effects of Atomic Radiation (UNSCEAR). Sources and Effects of Ionizing Radiation (Report to the General Assembly) (New York: United Nation) (2000).

[23] Testa S.M.. Geological Aspects of Hazardous Waste Management, CRC Press, USA, ISBN: 0-87371-630-2. 1994. p:206.

[24] Quindós L.S., Fernández P.L., Soto J., Ródenas C., Gómez J., Natural radioactivity in Spanish soils Health Phys. 66 (1994) 194-200.

[25] Guidotti L., Carini F., Rossi R., Gatti M., Cenci R. M., Beone G. M., Gammaspectrometric measurement of radioactivity in agricultural soils of the Lombardia region, northern Italy $\mathrm{J}$. Environ. Radioactiv. 142 (2015) 36-44 
[26] Santawamaitre T., Malain D., Al-Sulaiti H.A., Matthews M., Bradley D.A., Regan P.H., Nucl Instrum Methods Phys Res A . 652 (2011) 920-924.

[27] Fadol N., Salih I., Idriss H., Elfaki A. and Sam A., Investigation of Natural Radioactivity levels in Soil Samples from North Kordofan State, Sudan, Res. J. Physical Sci, 3, 1 (2015).

[28] Adukpo O.K., Faanu A., Lawluvi H., Tettey-Larbi L., Emi-Reynolds G., Darko E.O., Kansaana C., Kpeglo D.O., Awudu A. R., Glover E.T., Amoah P.A., Efa A.O., Distribution and assessment of radionuclides in sediments, soil and water from the lower basin of river Pra in the Central and Western Regions of Ghana, J. Radioanal. Nucl. Chem.303 (2015) 1679-1685.

[29] Ononugbo C.P., Avwiri G.O., Ogan C.A., Natural Radioactivity Measurement and Evaluation of Radiological Hazards in Sediment of Imo River, In Rivers State, Nigeria by Gamma Ray Spectrometry, J. Appl. Phys. 8 (2016) 7583. 